\title{
Locating Identity: Interpreting Food Images and Jade Snow Wong's Identity Construction in Fifth Chinese Daughter
}

\author{
Ruhang Qiu \\ School of Foreign Languages, Sun Yat-sen University, Guangzhou 510275, China \\ qiurh6@mail2.sysu.edu.cn
}

\begin{abstract}
Jade Snow Wong's autobiographical novel Fifth Chinese Daughter, as an early classic of Asian American literature, has aroused wide concern since its publication, in which, food images as important elements play a prominent role in the author's identity construction. Based on the theories of cultural identity, imagism, and feminist criticism, this paper focuses on the food images related to Jade Snow Wong's identity construction in Fifth Chinese Daughter, and reveals the influence of these images on her identity construction. Food images in this novel, as media connecting two different cultures and genders, help break the Chinese American women's marginalized status in culture and gender, and promote their construction of cultural identity as well as gender identity.
\end{abstract}

Keywords: Jade Snow Wong, Fifth Chines Daughter, Food images, Identity construction.

\section{Introduction}

Cultural identity is acquired postnatally and is not fixed. Edward Seward thinks that "human identity is not naturally formed, but artificially constructed, sometimes even made out of nothing." Jade Snow Wong's cultural identity was also constructed postnatally, which was inseparable from her personal experiences in America. Jade Snow Wong, as an Asian American writer, accepted the cultures of the two different worlds, but meanwhile she was separated from the two different cultures and felt strange about them. On one hand, she tended to be confused about her cultural identity, and although she wanted to fit in American culture, she always felt that she could never completely incorporate into it. On the other hand, although she yearned for Chinese culture, she always felt strange when returning to Chinese culture (Xu, 20). For Wong, the boundary between her self-identity and his self-other identity is blurred, and she has a contradictory attitude towards both Chinese and American culture, both opposing and deferring to their cultural values, which makes her anxious about her cultural identity. Both Chinese culture and American culture have a great influence on her, contributing to her complicated cultural identity.

Aside from the anxiety of cultural identity, Jade Snow also felt anxious about the inequality and discrimination of female exerted by the patriarchal society. According to Simone de Beauvoir (1952), one is not born, but rather becomes, a woman. The traditional definition of women in patriarchal society limits women's freedom. Jade Snow Wong, influenced by Chinese culture, was indoctrinated with the traditional gender definitions from an early age by her father. With her awakening of female consciousness, she gradually resists the male authority. In this novel, she uses lots of food images to express her questions on traditional gender definition and resist the patriarchal society.

According to Ezra Pound, an American imagist poet, "an image is a complex of reason and emotion presented in an instant." The image advocated by imagist poets is a kind of fictionalized image that focuses on the subject's thoughts and emotions. Images are closely related to symbols. "An image can be transformed into a metaphor once, but if it is repeatedly presented, it becomes a symbol" (Wang, 258). From this point of view, repetitive images have certain symbolic meanings. In addition to their own meaning, such images also have a strong subjective color of the writer and a unique cultural connotation. Cultural identity is related to people, and images are related to works. The main images in the works can reflect the author's writing attitude and cultural background to a certain extent. Wong, influenced by two different cultures, has a rich life experience. The recurring food images like rice, etc. in her novel reflect her complex identity, and exert a vital influence on her identity construction.

Fifth Chinese Daughter, as an early classic Asian American literature that has never been out of print, contributes the development of Asian American literature and arouses wide attention from scholars both at home and abroad. In recent years, many foreign scholars have conducted comprehensive studies on the themes, conflicts of Chinese and American cultures, identity issues, etc., while few focuses on the food images in this novel. With the development of Asian American literature, domestic studies of Fifth Chinese Daughter increase rapidly. Most of the studies hold that identity issue is a vital theme in this novel. Wang Zhenyin's Exploration on the Theme of Jade Snow Wong's Fifth Chinese Daughter analyzes the theme of this novel, arguing that this novel reflects the yearning for American culture and the alienation from Chinese culture of Chinese Americans (Wang, 2007). Xu Meiting's Post-colonial Interpretation on Jade Snow's Identity Construction Dilemma in Fifth Chinese Daughter also analyzes the dilemma, cultural identity and significance of Jade Snow's identity construction (Xu, 2017). In addition, a few articles also think that food images play a vital role in this novel, such as Dong Meihan's The Food 
Narrative Tradition of Chinese American Female Literature in the Historical Context (Dong, 2014). Liu Qinli's Hungry Daughter's Quest-Food, Women and Identity in Fifth Chinese Daughter, The Woman Warrior, The Joy Luck Club discusses women's desire for food and women's identity crisis through analysis of food images (Liu, 2006).

Although studying food images and identity construction in this novel, this paper is different from other studies on Jade Snow Wong's identity and the food images at home and abroad. Based on the studies of previous scholars on this novel, this paper attempts to interpret how food constructs Jade Snow Wong's dual cultural identities and female consciousness through analyzing the changes of attitudes towards food and the symbolic meaning of the food images in this novel. This paper argues that food images in this novel, as media connecting two different cultures and genders, help break the Chinese American women's marginalized status in culture and gender, and promote their construction of cultural identity as well as gender identity.

\section{Out of the Cultural Other: Food Images and Construction of Cultural Identity}

In the mid-19th century, influenced by the Gold Rush in America, large quantities of Chinese people flooded into America, hoping to realize their dreams there; however, after they arrived there, their living conditions were not improved, and they did not integrate well into American culture. These Chinese Americans never got rid of the cultural other status and could not be accepted by American society (Liu, 2019:122). They were always discriminated by American society. It was under such background that Jade Snow Wong wrote her autobiographical novel, Fifth Chinese Daughter, aiming at subverting the stereotypes of Chinese Americans in American mainstream society. As Maud Ellman (1993) brilliantly outlines it in The Hungry Artist: Starving, Writing and Imprisonment, Hegel, Feuerbach, Marx, and Freud all agree that "eating is the origin of subjectivity". Food is closely related to human beings and exerts a great impact on the identity construction of them. In this novel, food images appear many times and run through the whole novel, helping the characters to find and construct their cultural identities.

Though Chinese Americans live in America and receive the American education, they also suffer from discrimination from American society (Liu, 2018: 141). They often feel confused and rootless between mainstream American culture and traditional Chinese culture, and they struggle to find their own identity. Food, as the basis of human survival, is necessary for human beings, and no matter which race, it cannot leave food; therefore, different characters' attitudes towards food in the novel can to a certain extent reflect their cultural identity. Fifth Chinese Daughter narrates the story of Jade Snow Wong's growing experience, whose life can be divided into different stages (Zhang, 61). The meaning of food is not fixed but flexible, and sometimes even contradictory in these different stages, which reflects her complicated attitudes towards her cultural identity.

\subsection{The Lost Other: Pursuit of Identity}

\subsubsection{Proud of Chinese Culture}

When Jade Snow was still a little girl, she lived in Chinatown. In the novel, she describes many foods which are necessary on tradition Chinese festivals, reflecting that she is immersed in Chinese culture. Below is her description of foods on the New Year:

\begin{abstract}
Jade Snow helped Mama pass sweetmeats and red melon seeds to their guests. The sweetmeats were candied melon, coconut, or kumquats, and lichee nuts from China. The red melon seeds were consumed by the visitors with remarkable skill....The red and green colors, the fruit, the green plants, the flowering branches, the seeds, the sweets-all were propitious: they meant life, new life, a fruitful life, and a sweet life. (Wong, 51)
\end{abstract}

From the vivid description of foods on New Year, we can see that these foods are endowed with special cultural meanings, that is, sweet and happiness. Sweetmeats, red melon seeds, lychee nuts, etc., these Chinese traditional foods convey Jade Snow Wong's love for Chinese food and Chinese culture. She enjoys these colorful and delicious Chinese foods, which, in fact, also expresses her pride as a Chinese and shows she is totally immersed in Chinese culture.

When Jade Snow was gradually growing up, her father taught her to be a filial child through making her realize the importance of food. Her father told her the importance of rice to Chinese people and the need to be careful in cooking rice. Rice and cooking rice make her become filial, obedient and careful, which constructs her identity as a Chinese.

\begin{abstract}
Daddy, who had previously decided on the kind the rice dealer recommended, was suddenly aroused, "What is more important than the rice which we eat twice a day and which is our main food? It is what we are, or we are what it is. Better to have what we want at whatever price, and economize on something else. It is decided-we shall have this most expensive type." (Wong, 71)
\end{abstract}

Although the price of rice from China was very high, her father still decided to buy it, because he wanted to tell his families, especially children, that they should never forget their Chinese cultural identity. Food, here, is used to remind the second-generation Chinese Americans of their cultural identity. Her father not only told children the importance of rice to Chinese people, but also constructed children's cultural identity through rice. In addition, her father also used the process of cooking rice to construct the cultural identity of Chinese-American daughters.

It was first dampened with a little water, then rubbed for a while with both hands (if you were a child like Jade Snow) or with one hand (if you were a grownup). White starch would come off the rice 
and bleed into the water. You rinsed after the thorough first rubbing of about a hundred strokes. Then rub, scrub, and rinse again. Rub, scrub, and rinse again. Then rinse, rinse, rinse. Three scrubbings; six rinsings; these were the minimum treatments. When the water came out clear, the rice had been thoroughly cleaned.

If by carelessness one forgot to turn down the flame when the water boiled, the rice would scorch. At times, this could happen in the best of families, but Daddy had a remedy. He would place a little saucer or Chinese teacup full of cold water in the pot on top of the rice to absorb the scorched taste. (Wong, 69)

The process of cooking rice was described in great detail by her father, which also reflected some characteristics of Chinese people, namely, carefulness, patience and diligence. In the process of learning to cooking rice, Jade Snow learned to be gentle, careful, patient and hardworking like many traditional Chinese women, and her positive attitude towards cooking rice indicated that she was proud of her Chinese cultural identity (Zhang, 61). When she first came into contact with American culture later, she felt very anxious. As we know, turkey is a common food on the western dining table, and it is also an essential delicacy in major western festivals such as Christmas Day and Thanksgiving Day; however, when Jade Snow saw the turkey for the first time, she was extremely frightened. Later, Grandma cured Jade Snow with herb tea. Here, Chinese food (i.e. herb tea) and Chinese culture dispelled her fear of strange food (i.e. turkey) and strange culture (i.e. American culture). Although later her father explained to Jade Snow the similarities between turkey and chicken, which is a common poultry in China, she still could not accept to eat turkey because only Chinese food and Chinese culture can give her a sense of security. Her attitude towards Chinese food shows that she is proud of Chinese culture, and Chinese food constructs her Chinese cultural identity.

\subsubsection{Yearning for Incorporation into American Culture}

With Jade Snow growing up, her attitude towards food changed accordingly. When she was old enough to go to school, she was sent to a public school in America, and first got in touch with American culture. One day, Miss Chew, her teacher brought several cases of whipping cream to class and announced, "We are going to make butter" (Wong, 24). Although Jade Snow was very skeptical- "Butter? Wasn't that what one bought at a store in a cube, wrapped with paper? Did one ever 'make' it?" (Wong 24) — she still followed what Chinese culture taught her, that is, to be an obedient child. As an obedient daughter, she remembers her mother's words, "Never question the actions of your teacher" (Wong, 25). Hence, she followed Miss Chew's instructions without asking any question.

After the cream had been churned for some time, sure enough, yellow flecks appeared, and then joined and thickened into a lump of butter! Jade Snow experienced a wonderful new feeling-the pride of personal creation. And when she smeared her own butter made with her own hands on the crackers Miss Chew provided, she thought that she had never tasted anything more delicious in all her life! (Wong, 25)

Making butter by herself enabled Jade Snow to enjoy the process of self-creation. American educational methods, totally different from Chinese education, let her not only know how to make butter, but more importantly, let her realize the existence of herself (Zhang, 62). Her experience of making butter implied that she is no longer just following her father's instructions, but could also make her own choice, which also showed her transformation of self-identity, that is, she was not blindly immersed in Chinese culture, and began to consider "who am I" (Liu, 2018:142). When her mother used different foods to compare different races, Jade Snow saw the superiority of western culture.

\section{"I (Mother) guess I have not yet told you (Jade Snow) where babies come from. They are roasted at the hospital ovens. There are three kinds of babies. When they are nearly done, they are white foreign babies. When they bake a little longer, they become golden Chinese babies. Sometimes they are left in too long, and they become black babies!" (Wong, 36)}

Her mother's comparing different skin colors to bread with different colors made Jade Snow see the superiority of American culture, and she wanted to integrate into it. However, her working experience in a "political couple" family made her realize the discrimination of American society against Chinese Americans. She felt confused. The more she knows about American culture, the more confused she becomes.

When Jade Snow graduated from middle school, she wished that her father would support her to go to college, but he refused her quest. The experience of working in white family made her believe that she could finish college on her own, so she earned money by cooking dinner for white family and finished her studies. Although she had to cook western food and do much housework, she still felt that she had her own freedom, and began to realize that she is an independent individual. Despite encountering the discrimination of American society, she made great efforts to learn American culture and wanted to let mainstream culture accept herself. However, racial discrimination did not disappear with her eagerness to integrate into the mainstream culture $(\mathrm{Xu}, 26)$. When she was cooking dinner for the family, she was always monitored by the hostess, which indicated that the so-called freedom and democracy are limited for Chinese Americans in America. In American culture, Jade Snow and other Chinese Americans are always cultural others and they are not accepted and recognized (Liu, 2018:142). She desired to integrate into American culture, but the American culture 
always refused to accept Chinese Americans, which made her lost herself and face identity crisis.

\begin{abstract}
That afternoon was a torturous nightmare and a fever of activity to manage another meringue cake, to get rolls mixed, salad greens cleaned and crisped, vegetables cut, meat broiled, the table set, and all the other details of a "company" dinner attended to. By the time she was at last washing the dishes and tidying the dining room she felt strangely vague. She hadn't taken time to eat her dinner; she was too tired anyway. How she wished that she had been asked to cook a Chinese dinner instead of this interminable American meal, especially that cake! (Wong, 130)
\end{abstract}

She witnessed the unequal and unfair treatment of Chinese Americans, and her description of cooking western food showed her attitudes towards American culture. Cooking western food such as hamburgers, pizzas, vegetables and sandwiches became "a torturous nightmare" for Jade Snow, and the trivial process of making meringue cakes made her yearn for Chinese food. "How she wished that she had been asked to cooked a Chinese dinner instead of this interminable American meal, especially that cake!” (Wong, 130) After doing all this, she began to rethink her cultural identity.

\subsection{Reconciliation of the Dual Cultural Identities}

In Fifth Chines Daughter, food images witnessed Jade Snow's changing attitudes towards her culture identity, that is, from enjoying Chinese culture to being confused about her cultural identity, finally to accepting her special cultural identity; and we can see her changing attitudes through interpreting the meaning and function of those food images. Her father's teaching her how to cook rice made Jade Snow gradually acquire traditional Chinese women's qualities, i.e. patience, obedience and diligence, which led to her later be accepted by American society. As Suan Kalcik once put it, "White Americans eat foods of different races, and their absorbing and digesting them symbolizes their acceptance of these races and cultures." (Xu, 33) When Jade Snow cooked for white family, her delicious food earned her praises from them, and the musicians on the table were no longer talking about music, but talking about Chinese food with her, which showed that her skillful cooking skills won her acceptance and recognition from American society.

When Jade Snow was studying at Kapiolani College, she stayed at the dean's home. her diligence, seriousness and patience won her the appreciation of the dean, and the dean suggested that she invite friends to here so that she would not feel lonely, and that she could cook Chinese food for her friends, which showed that Chinese food cooked by Jade Snow could help her to be accepted by American society. She accepted the dean's suggestion, and racked her brains to prepare food carefully in order to gain their acceptance.

After class on Tuesday, she came back from the neighborhood grocery store and meat market with the following items: a pound and a half of ripe tomatoes, a pound of yellow onions, a bunch of green onions, a large green pepper, a head of celery, a dozen eggs, a bottle of dark soy sauce which had been bottled for American consumption, a half-pound slice of raw ham, a pound of flank steak, and a box of small-sized long-grain white rice. The rice and soy sauce were chosen after weighty misgivings, but they had to do. The other items were for a minimum menu; even for an ordinary dinner, Chinese cooking involved small quantities of several different meats and vegetables. (Wong, 162)

Jade Snow won the recognition and friendship of her white friends with Chinese food, which also made these white girls curious about Chinese culture and Chinese ideology, then Jade Snow actively presented them with the positive aspects of Chinese culture so as to gain the recognition of them. When she successfully worked in an American company, her excellent cooking skills and outstanding quality and that Chinese culture had taught her won her recognition from colleagues once again, and her white colleagues expressed their acceptance of her with food. When Jade Snow was ill, her white colleagues gave her candy and gifts. They expressed their acceptance of her with food and treated her as a friend. Food has become a bridge between two groups and two cultures, and constructed her dual cultural identity.

\section{Out of the Second Sex: Food Images and Construction of Female Identity}

\subsection{Gender Discrimination in Fifth Chinese Daughter}

In Fifth Chinese Daughter, the female characters' position in the family and marriage can to a certain extent reflect the social discrimination of women at that time. When Jade Snow's brother Forgiveness from Heaven was born, and her father was extremely happy. He celebrated the birth of Forgiveness from Heaven with abundant Chinese foods for the fact that in traditional Chinese family, only boys can pass down the family lineage from generation to generation. When Jade Snow wanted to go to college and hoped that her father can give financial support to her to finish her studies, her father refused her quest and said that the money he earned was used to support Forgiveness from Heaven to go to school. In traditional Chinese families, only sons can naturally inherit the family business, while girls cannot, just for the benighted fact that girls will become the members of other family in the future (Liu, 2006: 32). Discrimination of women is also common in American society (Liu, 2019: 121). In this novel, Jade Snow's boss told her that in such a competitive society, women can never get the same treatment as men, no matter how smart and capable women is, and in the factory where Jade Snow works, men are paid twice or more than women for the same job.

From what mentioned above we can see that women are discriminated against in both Chinese culture and American culture. Chinese American women are eager for equality and want to seek equal rights in such a so-called free and equal 
country, but they are discriminated against by two cultures, i.e. the American culture against Chinese Americans and the gaze on women from patriarchal society.

\subsection{Awakening of the Female Consciousness}

In Fifth Chinese Daughter, since Forgiveness from Heaven was born, the whole family had prepared all kinds of foods to celebrate his birth. Jade Snow's vivid description of the celebration for her brothers' first month implies the embryo of her self-awareness of gender. The whole family, including aunts and female cousins, came to help with the celebration and they felt that "it was the happiest work they had ever done" (Wong, 38). "Laughter, excitement, and anticipation made light work of the activities" (Wong, 39). However, someone said, "This joyfulness springs only from the fact that the child is at last a son, after three daughters born in the fifteen years between Blessing from Heaven and him. When Jade Precious Stone was born before him, the house was quiet. There was no such display" (Wong, 39). People's talking about Forgiveness from Heaven's birth and the abundant foods on the celebration made her realize the low status of women in the family, and she experienced the inequality between men and women in the family for the first time.

Later, her sister's wedding made her realize the low status of women in patriarchal society again. "Between the sheets of the bridal bed they were now putting peanuts, oranges, Chinese dates, lichee nuts and so on" (Wong, 145). These are all fruits or seeds, and have special cultural meanings. Rice means that the bridegroom's family expects the bride to bring prosperity and wealth to them, while Chinese dates, peanuts and lichee nuts symbolizes that they expect the bride to give birth to a son. The bride's role in the bridegroom's family is just to give birth to a son to carry on her husband's family line, which indicates that women are oppressed in that patriarchal society (Zhang, 62).

With Jade Snow's growing up and her increasing understanding of western culture, her female consciousness is gradually awakening. The making of butter enhanced her independence as an individual, and made her understand that as an individual, she had to fight for equal right and decided her own life; therefore, when she graduated from high school, she made up her mind to go to college on her own, though her father did not give her financial support. Through cooking dishes and doing housework in several white American families, she earned money and finished her studies.

\subsection{A Person as well as A Female}

Food images in this novel show women's suffering and low status, but meanwhile women use food to express their voice and construct their own identity in the patriarchal society. Women use food to express their voice, protesting against the patriarchal society, and resist the gender discrimination in the patriarchal society. In this novel, the special celebration for her brothers' first month stimulated her gender awareness and her sister's unconscious explanation of why there were so many delicious foods, e.g. red eggs, pickled pig's feet on the table made her suddenly realize the unequal status between male and female. Although Jade Snow received Chinese traditional gender education, she did not accept the gender role of women in Chinese traditional culture. She got strength from food, and used it to resist male authority, so as to achieve her goal of pursuing equal dialogue between genders (Zhang, 62). For example, when she was in primary school, the experience of making butter made her become confident, and it was this experience that laid the foundation for her economic independence when she was in college. Although her father refused to give her financial support, she earned money by cooking dishes for white people, and won herself the opportunity to go to school. The experience of cooking dishes in white American families also made her accepted by white people and mainstream American culture.

\section{Conclusion}

In Fifth Chinese Daughter, the description of food can be found everywhere, which plays an important role in the whole novel. The description of food and the unique meaning of food images show Chinese American women's confusion about their identity. In this novel, food, as a unique weapon, plays a vital role in the construction of Chinese American women's identity, and Chinese American women's consciousness of gender inequality and acceptance of female identity are accomplished by food. As Chinese American women, they not only learn about Chinese history and culture through food, but also let American society know Chinese culture through food. Food exerts a great influence on building the cultural identity and female identity of Chinese American women, and promotes the communication between Chinese and Western cultures, which to a large extent is also one of the most important reasons why the author Jade Snow Wong employs many food images in this novel. Based on the theories of cultural identity, imagism and feminist criticism, this paper interprets how food images construct Jade Snow Wong's cultural identity and female consciousness through analyzing the changes of attitudes towards food and the symbolic meaning of these images. Since Chinese American literature is an important branch of American multiethnic literature, it is of great significance for us to interpret Chinese American writers' exploration of their own cultural identity, and analyze the confusion, helplessness and struggle of them in the two worlds and cultures, which will definitely deepen our understanding of the diversity of American literature.

\section{References}

[1] Beauvoir, Simone de. The Second Sex. New York: Vintage Books 1989, c1952. Print.

[2] Ellmann, Maud. The Hunger Artists: Starving, Writing and Imprisonment. London: Harvard University Press, 1993.

[3] Dong, Meihan. Food Narrative Tradition of Chinese American Female Literature in the Historical Context. Literary Contention. 1(2014) Vol.9: 136-141.

[4] Guo, Liying. Changing Cultural Meaning of "Food" as Ethnic Symbol in Literary Works of Three Chinese-American Women Writers as the Second 
Generation of Immigrants. Journal of Mudanjiang College of Education. 128(2011) Vol.4: 13.

[5] Liang, Yanli, et. Food Narrative in Chinese American Literature. Literary Contention. 1(2013) Vol.2: 188-190.

[6] Liu, Qinli. Hungry Daughter's Quest-Food, Women and Identity in Fifth Chinese Daughter, The Woman Warrior, The Joy Luck Club. M.A. Thesis of Sichuan University, 2006.

[7] - Identity Seeking in Food and Thought: Interpreting Jade Snow Wong's Fifth Chinese Daughter. Contemporary literary world. 2(2018) Vol.2: 141-143.

[8] Liu, Sitong. On the Construction of Chinese American Cultural Identity by Food Description in The Joy Luck Club. Literary Criticism. 2(2019) Vol.11: 122-123.

[9] Xu, Meiting. Post-colonial Interpretation on Jade Snow's Identity Construction Dilemma in Fifth Chinese Daughter. M.A. Thesis of Guangxi University, 2017.

[10] Wang, Xianxu, Wang Youping. A Critical Term in Literary Theory. Beijing: Higher Education Press, 2006.

[11] Wong, Jade Snow. Fifth Chinese Daughter. New York: Harper, 1950.

[12] Zhang, Hongwei, et. Analysis of the Role of Food in Identity Construction in the Fifth Chinese Daughter. Journal of Beijing University of Aeronautics and Astronautics. 2(2008) Vol.21: 60-63. 